\title{
Influence of Lifestyle Factors on Breast Cancer Risk
}

\author{
Max Dieterich $^{a} \quad$ Johannes Stubert $^{\mathrm{a}} \quad$ Toralf Reimer $^{\mathrm{a}} \quad$ Nicole Erickson $^{\mathrm{b}} \quad$ Anika Berling ${ }^{\mathrm{b}}$ \\ a Department of Obstetrics and Gynecology, Breast Center, University of Rostock, Germany \\ ${ }^{b}$ Department of Prevention, Rehabilitation and Sports Medicine, Technical University Munich, Germany
}

\section{Keywords}

Breast cancer - Prevention - Lifestyle - Risk factors

\section{Summary}

Breast Cancer (BC) is a life-changing event. Compared to other malignancies in women, $\mathrm{BC}$ has received considerably more public attention. Despite improved neoadjuvant, adjuvant, and palliative treatment strategies for each characteristic molecular BC subtype, recommendations for evidence-based preventive strategies for $B C$ treatment are not given equivalent attention. This may be partly due to the fact that high-quality long-term prevention studies are still difficult to carry out and are thus underrepresented in international studies. The aim of this review is to discuss the most relevant lifestyle factors associated with BC and to identify and discuss the evidence supporting practical prevention strategies that can be used in everyday clinical practice.

\section{Introduction}

Every year, 75,000 and 234,000 patients are diagnosed with breast cancer (BC) in Germany and in the USA, respectively $[1,2]$. With $\mathrm{BC}$ being the number one cancer in women, public interest in treating and preventing $\mathrm{BC}$ is high. Consequently, it is not surprising that far more clinical trials and different treatment strategies are available with regard to $\mathrm{BC}$ compared to other gynecological cancers. Great improvements in $\mathrm{BC}$ treatment and care have been made over the past decade, which has contributed to a significant increase in overall survival of $\mathrm{BC}$ patients. On the other hand, preventing $\mathrm{BC}$ has been an issue that has not been given adequate attention. This is especially surprising considering that in other widespread diseases like cardiovascular or infectious diseases prevention is the first approach to 'treatment' [3]. When considering that 1.67 million new $\mathrm{BC}$ cases are diagnosed per year worldwide, the need for preventive action is given a completely new dimension [4]. We know from epidemiological studies that lifestyle factors play an important role in the development of BC. For example, daughters of Asian women who have migrated to the USA revealed an increasing risk of developing BC, which was attributed to the exposure to different lifestyle and nutritional factors [5]. Further evidence that changing lifestyle patterns influence the development of $\mathrm{BC}$ can be found in the steady increase in $\mathrm{BC}$ incidence in Asian countries during the last few centuries. Again, this finding is linked to a movement toward a more modern and 'Western' lifestyle [6]. Consequently, modifiable and lifestyle risk factors are important to consider when developing a strategy for BC prevention. Non-modifiable risk factors like higher age, genetic risks, family history of BC, personal breast history (pre-malignant lesions), breast density, thorax radiation, and number of menstrual cycles during lifetime are not part of this manuscript. The aim of this review is to give an overview of the most significant modifiable BC risk factors and to discuss them in a clinical context.

\section{What Are Lifestyle Factors and How Are They Defined?}

The World Health Organization (WHO) defines a risk factor as 'any attribute, characteristic or exposure of an individual that increases the likelihood of developing a disease or injury'. Nevertheless, the presence of one or more risk factor(s) does not necessarily result in the development of the disease. Therefore, a lot of women may present with one or more BC risk factors, yet never develop BC. On the other hand, patients with no risk factors can also develop BC. Differences in indi-

\section{KARGER}

Fax +497614520714

\section{(c) 2014 S. Karger AG, Freiburg}

1661-3791/14/0096-0407\$39.50/0
Max Dieterich, M.D.

Universitätsfrauenklinik Rostock

und Poliklinik am Klinikum Südstadt der Hansestadt Rostock

Südring 81, 18055 Rostock, Germany

max.dieterich@uni-rostock.de 
vidual genetic variation, polymorphisms, and mutations could explain the differing effects of the same substance in different people. Moreover, duration, intensity, and cofactors could play a role in influencing effects. This issue also helps illustrate the difficulty in evaluating and interpreting studies concerning $\mathrm{BC}$ risk factors and the heterogeneity of this disease. Furthermore, risk factors like lifestyle can change over time. Modifiable lifestyle risk factors can thus also actively be influenced by women in order to reduce their BC risk, and the intention of this article is to introduce and discuss such factors.

\section{Obesity}

The association between an increased risk of developing postmenopausal BC and body weight is well documented. Adult weight gain and a body fatness and distribution (defined as a body mass index (BMI) above $25 \mathrm{~kg} / \mathrm{m}^{2}$ and abdominal fatness) are all associated with an increased risk of postmenopausal BC $[7,8]$. These relationships remain consistent among most major studies. Furthermore, support is found in data demonstrating that, when compared with normal-weight women (i.e. women with a BMI of $18.5-25 \mathrm{~kg} / \mathrm{m}^{2}$ ), the relative risk (RR) for postmenopausal $\mathrm{BC}$ is around 1.5 for overweight women $(\mathrm{BMI}>25$ $\left.\mathrm{kg} / \mathrm{m}^{2}\right)$ and $>2$ for obese women $\left(\mathrm{BMI}>30 \mathrm{~kg} / \mathrm{m}^{2}\right)$ [9].

However, the role that body weight plays in the $\mathrm{BC}$ risk is quite complex and not fully understood. Since a high body weight is known to be associated with increased inflammation and alterations in serum levels of potential growth regulators such as adiponectin, leptin, and estrogen, this most likely also plays a role in the association with an increased postmenopausal BC risk [10]. Still, weight appears to have a different impact on BC risk across the lifespan. Obesity during childhood and adolescence is inversely related to the premenopausal incidence of BC, independent of the adult BMI [11]. When adult weight was analyzed in premenopausal women, epidemiological data showed that a higher weight is inversely related to the premenopausal $\mathrm{BC}$ risk [7, 8]. A meta-analysis including 50 studies found an inverse, but non-significant association between BMI and BC risk during the premenopausal period [12]. Another study found that a loss of at least 4.5 $\mathrm{kg}$ between the ages of 18 to 30 years was associated with a reduced risk of $\mathrm{BC}$ in the premenopausal period [13].

Despite the differing impact of weight on the $\mathrm{BC}$ risk during different life phases, research clearly shows that the avoidance of adult weight gain and the ability to keep one's weight within the ranges of a normal BMI $\left(18.5-25 \mathrm{~kg} / \mathrm{m}^{2}\right)$ reduces the risk for postmenopausal BC.

\section{Smoking}

Smoking tobacco is well known to be carcinogenic, not only for BC but for most types of cancer. Its carcinogenic ef- fects are caused by aromatic hydrocarbons contained in tobacco, which, together with genetic polymorphisms in the $\mathrm{N}$ acetyltransferase-2, may influence BC development [14]. It is estimated that tobacco consumption is the cause of $21 \%$ of all cancer mortalities worldwide [15]. With regard to BC, multiple studies have been performed, with diverse outcomes. Animal models provide evidence that tobacco induces BC. 10 years ago, the US Surgeon General concluded in a report of the United States Health Service that no fundamental evidence exists (in studies published until 2002) that supports the relationship between active smoking and BC. In 2012, the International Agency for Research on Cancer updated their monographs, confirming a positive association between tobacco smoking and BC. The 2014 report of the US Surgeon General revised their 2004 statement, now to report an estimated $10 \%$ increased $\mathrm{BC}$ risk for women with a history of smoking.

Data from the American Cancer Society's Cancer Prevention Study II (CPS-II) Nutrition Cohort further supports the carcinogenic effect of smoking [16]. They found a higher incidence of $\mathrm{BC}$ in current and former smokers than in people who had never smoked.

Interestingly, a recent epidemiological study of 73,909 Canadians found no association between any smoking exposure and risk of $\mathrm{BC}$ (hazard ratio $(\mathrm{HR})=1.00,95 \%$ confidence interval $(\mathrm{CI})=0.87-1.17)$. Despite these findings, enough evidence exists to show that smoking should be regarded as a possible risk factor for $\mathrm{BC}$.

\section{Alcohol Consumption}

Although ethanol is not a carcinogen, its metabolized compounds have carcinogenic potential. Ethanol further potentiates the carcinogenic effect of tobacco metabolites and suppresses hepatic clearance $[17,18]$. Animal models show that ethanol induces mammary epithelial cell growth, resulting in increased serum concentrations of estradiol in premenopausal women [19]. The World Cancer Research Fund (WCRF) recommends a maximum alcohol consumption equivalent of $10 \mathrm{~g}$ of ethanol per day to reduce the BC risk [7]. The Women's Health Initiative Study (2014) found a reduced risk of BC at and below this level of alcohol consumption, confirming this recommendation [8]. Further studies have observed that alcohol consumption above this threshold is strongly correlated with an increased BC incidence in women. In fact, a $10 \%$ increased risk of $\mathrm{BC}$ has been reported for every additional $10 \mathrm{~g}$ of ethanol consumed daily [20-23]. 2 recent studies suggest that even alcohol consumption at or below $10 \mathrm{~g}$ ethanol per day may also be associated with an increased risk of BC [24, $25]$. Epidemiological data illustrate that $4 \%$ of the BC cases in developed countries are at least partially caused by alcohol consumption. This evidence further supports the recommendation to keep alcohol consumption as low as possible [22]. 


\section{Shift Work Factors}

Being exposed to light at night may increase the BC risk. This risk increase stems from a suppression of the normal production of melatonin at night. In turn, the suppression of melatonin increases the release of estrogen in the ovaries [26]. However, investigations regarding the effect of shift work on the development of $\mathrm{BC}$ are controversial. The differing results can be attributed to factors affecting data interpretation. For example, factors such as the total number of years doing shift work, doing night work as opposed to late and early shifts that only partly take place in the night, the number of shifts in a row, and the total number of night shifts worked must each be considered differently [27-29]. Additional confounding factors in these studies are due to differing definitions of the start and end times of night shifts and whether or not the shifts were carried out on a rotating basis [30]. Despite the difficulty of producing robust evidence, enough convincing data has been generated for the International Agency for Research on Cancer to classify night shift work as possible risk factor for BC in 2007. A systematic review and meta-analysis of 15 studies found an increased RR of 1.21 (95\% CI, 1.00-1.47; $\mathrm{p}=0.056)$ for developing BC among women who have ever worked night shifts [31]. Night shift workers who did this job for less than 8 years had an RR of 1.13 (95\% CI, 0.97-1.32; $\mathrm{p}=0.11$ ), and for long-term night shift workers ( $>8$ years) the RR was 1.04 (95\% CI, 0.92-1.18; $\mathrm{p}=0.51$ ). An increased BC risk was also postulated for flight attendants with international and overnight work exposure and nurses who worked night shifts on a long-term basis. However, the authors emphasize that their data must be interpreted carefully, due to the lack of homogeneity of the studies. It is also interesting to note that frequent jet lag, as demonstrated in studies of flight attendants, might have an identical effect on the BC risk [32]. Light is not the only factor that may play a role in the increased risk of $\mathrm{BC}$ among shift workers. Shift work often influences the lifestyle characteristics and is associated with a poorer dietary intake, a decrease in physical activity, an increase in alcohol consumption, and a reduction in time spent outside. These factors may represent a secondary effect that in turn correlates with the increased BC risk among shift workers [20]. Therefore, considering all of the available data, only weak evidence supports the relationship between shift work and an increased risk for BC.

\section{Antiperspirants}

Data on the effects of deodorant use and BC are inconclusive. Only few observational studies and review articles have been published for and against an increased BC risk [33-35]. A postulated increased $\mathrm{BC}$ risk in women using deodorants was based on the increased number of diagnosed BC cases in the upper outer quadrant, which was then correlated with a possible association of the use of antiperspirants in the axilla.
Additionally, deodorants contain chemicals such as parabens. Parabens have estrogenic properties and have thus also been associated with an increased BC risk [36]. Further chemical components with known estrogenic activity that can be found in deodorants include aluminum and triclosan [37]. Nevertheless, as to date, no convincing evidence exists that highlights a strong correlation between the use of axillary deodorants and an increased BC risk [38]. Therefore, more studies are needed before recommendations can be made.

\section{Breast Implants}

Breast augmentation is the most frequently performed aesthetic surgery in women within the USA [39]. Silicone breast implants are predominantly used for this purpose. Therefore, the effect of silicone on the induction or promotion of malignancy in breast tissue has also been the subject of comprehensive studies and reviews. However, the majority of the major studies did not reveal any correlation between BC and breast implants [40-45]. These studies do, however, provide comprehensive data as to the safety and effectiveness of silicone implants, focusing on the rupture rate and the incidence of leakage. These aspects are also an important part in the Food and Drug Administration (FDA) approval criteria for such implants. The data from the USA is consistent with the European data with regard to silicone breast implants used for aesthetic and reconstructive procedures. Likewise, no evidence exists on a potentially increased $\mathrm{BC}$ risk after aesthetic or reconstructive breast surgery using silicone implants [46].

Although no relationship between silicone breast implants and $\mathrm{BC}$ has been documented, evidence exists demonstrating an association of silicone implants and the development of an anaplastic large-cell lymphoma (ALCL). In the literature, about 34 cases of silicone breast implants have been associated with ALCL [47]. Although only a limited association can be interpreted from these data, with an estimated 5-10 million breast implant recipients worldwide, this number of ALCL cases is too small to support the conclusion that breast implants cause ALCL. Thus, when all existing evidence is considered, there are not enough data to support the link between breast implants and an increased risk of BC.

\section{Could a Healthy Diet Have a Role in the Prevention of BC?}

A well-balanced diet is a key component of an overall healthy lifestyle. However, investigations of the effects of healthy dietary behaviors on the $\mathrm{BC}$ incidence are confounded by the close relationship between diet and body weight, and the difficulty of separating the effects of one from the other. Therefore, evidence linking dietary behaviors independently to $\mathrm{BC}$ risk is limited. 
A Mediterranean dietary pattern consisting of vegetables, fruits, whole grains, fish, and olive oil has consistently been associated with a decreased risk of BC [48]. There is also some evidence that a diet rich in fruits and vegetables and high in dietary fiber may have a weak effect on BC risk reduction [8, 49-51]. The World Cancer Research Fund (WCRF) thus recommends eating 400-600 g of vegetables and fruits per day to help prevent $\mathrm{BC}$ [7]. This recommendation is also equivalent to the recommendations contained in the WHO's '5 a day' campaign [52]. While the reasoning and dosage recommendations may differ slightly, scientists around the world agree that an increased intake of vegetables and fruits may play an important role in reducing the BC risk.

Due to a possible association of the consumption of red and processed meats with a higher risk of $\mathrm{BC}$, the WCRF also recommends limiting these foods [7]. Specifically for BC, existing research questions the strength of the relationship between red and processed meat and BC risk [53, 54]. Thus, caution should be applied when making this recommendation.

\section{Physical Activity}

Physical inactivity is a stand-alone risk factor for several types of cancer [7]. There is convincing evidence that physical activity is protective against postmenopausal BC. Several mechanisms by which physical activity may protect against BC have been proposed. One reason may be the effect of physical activity on the endogenous steroid hormone metabolism and inflammation. Additional positive effects include a reduction of body fat, improvement of immune system regulators, and alterations in free-radical generation. The risk reduction attributed to physical activity was found to be up to $25-30 \%$, which is akin to the reduction brought about by hormone therapy [55]. However, in contrast to medical treatment, physical activity has few negative side-effects. Most study designs assigned metabolic equivalent task (MET) values to count and compare the physical activity levels. For example, an activity with a MET value of 3 is $1 \mathrm{~h}$ of moderate walking (e.g., 4 $\mathrm{km} / \mathrm{h}$ ). In the Women's Health Initiative Cohort Study, the greatest $\mathrm{BC}$ risk reduction was induced by regular moderate to strenuous activities, carried out between the ages of 35 and 50 years, among normal to moderately overweight women (BMI $<28.44 \mathrm{~kg} / \mathrm{m}^{2}$ ). In this cohort, there was also a positive correlation between the intensity of physical activity and the amount of risk reduction, ranging from 10\% ( $\leq 5 \mathrm{MET}-\mathrm{h} /$ week $)$ over $18 \%$ (5.1-10 MET-h/week) to $22 \%$ (> 40 MET-h/week) compared to inactive women. An increasing physical activity was also associated with a reduced BC risk in women who performed strenuous physical activity between the ages of 18 and 50 years. These effects did not occur for women in the highest tertile of the BMI $\left(\mathrm{BMI}>28.44 \mathrm{~kg} / \mathrm{m}^{2}\right)$ [56].

In 2010, a review including 73 prospective cohort and casecontrol studies reported an average risk reduction of $25 \%$ for those who were physically active. Those, who were physically active for $\geq 6.5 \mathrm{MET}$-h/week had an average risk reduction of $28 \%$. The largest benefits were found for a lifetime moderateto-vigorous-intensity physical activity after menopause for women of all body sizes, except for obese women (BMI > 30 $\mathrm{kg} / \mathrm{m}^{2}$ ). These findings were supported by various similar study results $[55,57]$.

The latest large cohort study analyzing 73,615 postmenopausal women also described a $25 \%$ lower risk for BC in the most active group ( $>42 \mathrm{MET}$-h/week) compared to the least active category (<7 MET-h/week) [58]. Walking seems to be the most frequent type of physical activity in this group. Those who walked for $\geq 7 \mathrm{MET}$-h/week had a $14 \%$ lower BC risk compared to women walking for $\leq 3 \mathrm{MET}-\mathrm{h} /$ week. However, the time spent sitting was not associated with an increased risk of $\mathrm{BC}$.

A case-control study found an association with lifetime moderate to vigorous but not with light physical activity (1.63.0 METs) and a reduced BC risk [59]. While most trials found a strong association between physical activity and a risk reduction of postmenopausal $\mathrm{BC}$, data for premenopausal BC is scarce and controversial $[7,55,57,60]$.

Since the effect of physical activity on the BC risk is clear, it has been hypothesized that physical activity, in combination with a Mediterranean diet, may also influence the incidence and progression of genetic forms of $\mathrm{BC}$, specifically in carriers of the BRCA1/2 mutation. This connection is currently being investigated in a multicenter, interdisciplinary, prospective, randomized study in Germany called LIBRE (Life-style Intervention in healthy and diseased BRca1/2 mutation carriErs). Preliminary results should be available within the next few months.

Considering all data, there is strong evidence for an association between physical activity and postmenopausal BC risk reduction. These data encourage the realization of intervention trials in primary and secondary BC prevention. Open questions to be addressed include more specific recommendations, such as what kind of exercise, which intensity level and which duration of physical activity bring the greatest risk reduction of pre- and postmenopausal BC.

\section{Hormone Therapy after Menopause}

Hormone therapy after menopause (HTMP) is a therapeutic option for women suffering from menopausal complaints like hot flushes and vaginal dryness. Menopausal symptoms can be controlled either by estrogen-only hormone therapy or by a combined continuous HTMP with estrogen and progesterone. Although most menopausal symptoms are related to the decline of estrogen levels, the addition of progesterone is recommended as progesterone reduces the risk of endometrial hyperplasia [61]. Although HTMP protects against coronary heart disease, osteoporosis and possible cognitive decline 
or dementia, it is associated with an increased risk for developing BC. Numerous studies have investigated this risk, concentrating on the association of HTMP and the development of BC. As a discussion focusing on the 'most important' results exceeds the capacity of this overview, the results of a comprehensive Cochrane meta-analysis from 2012 will be summarized [62]. In this analysis of 23 studies involving 42,830 women, a significantly increased risk of BC (after 5.6 years of use: absolute risk, 23/1000; 95\%, CI 19-29) was found among women using a combined continuous HTMP. The Million Women Study, which included 1,084,110 women from the UK aged 50-64 years, supported these findings, stating that a clearly increased risk of incidence and in fatal BCs was found among women on combined continuous HTMP [63]. This increased $\mathrm{BC}$ risk could also be quickly reduced by stopping HTMP [64]. In contrast, estrogen-only HTMP has not been associated with a significant increase in the risk of BC. This effect was support by data from the Women's Health Initiative study which followed women using estrogen-only HTMP for up to 7 years [65-67]. It seems that progesterone does have a negative effect on $\mathrm{BC}$, but this effect is not seen in endometrial and ovarian cancer. Additionally, norethisteron and levonorgestrel derivates found in progesterone seem to have a worse effect than progesterone itself. It should also be noted that the increase in breast tissue density caused by HTMP can lead to a delayed BC diagnosis.

General practice-oriented recommendations for the usage of HTMP can thus be summarized as follows [68-71]:

- HTMP can be recommended when menopause occurs in women younger than 45 years until the age of 50 years.

- Women who retain their uterus should use estrogen/progesterone combined HTMP.

- Estrogen alone should be used in women following a hysterectomy.

- Always start with the lowest effective dose of HTMP.

- Treatment of menopausal complaints should be limited as much as possible.

- Vaginal dryness can be treated with locally administered low-dose estrogen.

- The pros and cons for HTMP should be reevaluated every year.

Based on the available data, the use of HTMP for longtime therapy brings an increased risk for the development of BC. Women suffering from major menopausal complaints should start HTMP at the early onset of the menopause. Applying HTMP for a shorter time frame seems to carry less risk in healthy women, but all women on HTMP need to be informed about the possible consequences of HTMP.

\section{Diabetes Mellitus}

The relationship of diabetes mellitus (DM) and $\mathrm{BC}$ from a biological standpoint is not yet completely understood. Insu- lin itself is a potent growth factor. Patients suffering from type II DM are characterized by an insulin resistance combined with a secondary hyperinsulinemia. Hyperinsulinemia is associated with carcinogenesis as it is thought to directly stimulate the proliferative pathway after binding to the insulin receptors [72]. This hypothesis is strengthened by findings among patients receiving metformin. Metformin increases the insulin sensitivity and consequently decreases the hyperinsulinemia. A lower general cancer incidence was observed in patients with DM and metformin therapy compared to patients receiving insulin or a sulfonylurea, indicating that insulin sensitivity plays a role. Insulin-like growth factor (IGF)-1 plays an additional important role in carcinogenesis. By administering insulin, the production of IGF-1 binding protein is inhibited, increasing the bioactivity of IGF-1. The increased activity of IGF-1 may be problematic as it has more mitogenic and antiapoptotic potential than insulin. This can subsequently lead to an increased stimulation of neoplastic cells, which are activated by different downstream signaling pathways. Two major pathways have been identified to play a major role specifically in BC. One of these pathways is the PI3K/Akt/mTOR signaling pathway $(\mathrm{PI} 3 \mathrm{~K}=$ phosphatidylinositol 3-kinase, $\mathrm{mTOR}=$ mammalian target of rapamycin). The other pathway starts when the inhibitor of the oncogenic $\beta$-catenin signaling pathway is inactivated, leading to an activation of the $\beta$-catenin pathway, which in turn has been related to cancer stem cells and chemoresistance [73-76].

The WHO estimated a worldwide prevalence of DM of $171,000,000$ in the year 2000 , with a predicted increase to $366,000,000$ in 2030 [77]. Epidemiological evidence exists linking DM to an increased incidence of cancer, including BC [78-82]. A meta-analysis including 20 studies (5 case-control and 15 cohort studies) concluded that women with DM had a statistically significant $20 \%$ increased risk for BC (RR, 1.20; $95 \%$ CI, 1.12-1.28) [75, 83]. In further studies, the relative increased $\mathrm{BC}$ risk among patients with DM ranges from 1.2 to $1.5[72]$.

\section{Stress}

A prospective examination of 37,562 US women in the Nurses' Health Study indicates that job stress is not related to any increase in BC risk [84]. No further evidence exists that other life events like divorce, loss of job, disease, or death are related to $\mathrm{BC}[85,86]$.

\section{Other Lifestyle Factors}

Many other factors like pesticides used in agriculture or the exposure to chemical substances, electromagnetic pollution, environmental pollution, or cosmic radiation, as well as the use of cellphones, cosmetics, and bras, even television viewing 
time and others have been investigated regarding their influence on the $\mathrm{BC}$ risk. However, to date, no conclusive evidence has been generated.

\section{Conclusions}

Considering the fact that lifestyle modifications and small changes in daily habits may help to reduce the postmenopausal BC cases by up to $34 \%$, prevention strategies in the form of behavior modification should receive more focus [87]. This review illustrated the fact that $\mathrm{BC}$ is a multifactorial process in which isolated factors play a lesser role. Therefore, appropriate education programs addressing lifestyle changes are crucial in terms of preventing BC. These programs should be carried out by experts, begin during childhood and should contain information about the importance of a healthy dietary pattern, the avoidance of adult weight gain, physical activity, and the renunciation of alcohol and tobacco.

\section{BC Prevention Strategies (Adapted to National Cancer Institute Recommendations)}

- Start taking preventive measures early in childhood

- Eat several servings of vegetables and fruit per day

- Consume a diet rich in fiber (e.g. cereals and soy products)

- Maintain an ideal body weight (BMI $=20-25 \mathrm{~kg} / \mathrm{m}^{2}$ )

- Avoid animal fat - replace with unsaturated vegetable fat or fish oil

- Limit consumption of red meat to $140 \mathrm{~g}$ /day

- Avoid supplements in the form of vitamins, minerals, and trace elements

- Exercise regularly (2-3 h/week of moderate exercise)

- Abstain from alcohol and smoking

- Avoid unnecessary postmenopausal hormone use

\section{Disclosure Statement}

The authors reported no conflicts of interest.

\section{References}

1 Robert Koch Institute (RKI), Zentrum für Krebsregisterdaten, www.rki.de/Krebs/DE/Content/ Krebsarten/Brustkrebs/brustkrebs_node.html, 2014.

2 American Cancer Society: Cancer Facts and Figures 2013. Atlanta, American Cancer Society, 2014

$\checkmark 3$ Vogelstein B, Papadopoulos N, Velculescu VE, Zhou S, Diaz LA Jr, Kinzler KW: Cancer genome landscapes. Science 2013;339:1546-1558.

4 International Agency for Research on Cancer: GLOBOCAN 2012: estimated cancer incidence, mortality and prevalence worldwide in 2012. Lyon, International Agency for Research on Cancer/ World Health Organization, 2012. http://globocan. iarc.fr/Pages/fact_sheets_cancer.aspx (accessed June 24, 2014).

$\checkmark 5$ Ziegler RG, Hoover RN, Pike MC, Hildesheim A, Nomura AM, West DW, Wu-Williams AH, Kolonel LN, Horn-Ross PL, Rosenthal JF, Hyer MB: Migration patterns and breast cancer risk in AsianAmerican women. J Natl Cancer Inst 1993;85: 1819-1827.

6 6 Shin HR, Joubert C, Boniol M, Hery C, Ahn SH, Won YJ, Nishino Y, Sobue T, Chen CJ, You SL, Mirasol-Lumague MR, Law SC, Mang O, Xiang YB, Chia KS, Rattanamongkolgul S, Chen JG, Curado MP, Autier P: Recent trends and patterns in breast cancer incidence among Eastern and Southeastern Asian women. Cancer Causes Control 2010;21:1777-1785.

7 World Cancer Research Fund/American Institute for Cancer Research (AICR): Food, nutrition, physical activity, and the prevention of cancer: a global perspective. Washington, DC, AICR, 2007.

$\checkmark 8$ Thomson CA, McCullough ML, Wertheim BC, Chlebowski RT, Martinez ME, Stefanick ML, Rohan TE, Manson JE, Tindle HA, Ockene J, Vitolins MZ, Wactawski-Wende J, Sarto GE, Lane DS, Neuhouser ML: Nutrition and physical activity cancer prevention guidelines, cancer risk, and mortality in the women's health initiative. Cancer Prev Res (Phila) 2014;7:42-53.
9 La Vecchia C, Giordano SH, Hortobagyi GN, Chabner B: Overweight, obesity, diabetes, and risk of breast cancer: interlocking pieces of the puzzle. Oncologist 2011;16:726-729.

10 McTiernan A: Obesity and cancer: the risks, science, and potential management strategies. Oncology (Williston Park) 2005;19:871-881; discussion 881-872, 885-876.

11 Baer HJ, Colditz GA, Rosner B, et al.: Body fatness during childhood and adolescence and incidence of breast cancer in premenopausal women: a prospective cohort study. Breast Cancer Res 2005; 7:314-325.

12 Cheraghi Z, Poorolajal J, Hashem T, Esmailnasab $\mathrm{N}$, Doosti Irani A: Effect of body mass index on breast cancer during premenopausal and postmenopausal periods: a meta-analysis. PLoS One 2012; 7:e51446.

13 Kotsopoulos J, Olopado OI, Ghadirian P, Lubinski J, Lynch HT, Isaacs C, Weber B, Kim-Sing C, Ainsworth P, Foulkes WD, Eisen A, Sun P, Narod SA: Changes in body weight and the risk of breast cancer in BRCA1 and BRCA2 mutation carriers. Breast Cancer Res 2005;7:R833-R843.

14 Krajinovic M, Ghadirian P, Richer C, Sinnett H, Gandini S, Perret C, Lacroix A, Labuda D, Sinnett D: Genetic susceptibility to breast cancer in French-Canadians: role of carcinogen-metabolizing enzymes and gene-environment interactions. Int J Cancer 2001;92:220-225.

15 Ott JJ, Ullrich A, Mascarenhas M, Stevens GA: Global cancer incidence and mortality caused by behavior and infection. J Public Health (Oxf) 2011; 33:223-233.

16 Gaudet MM, Gapstur SM, Sun J, Diver WR, Hannan LM, Thun MJ: Active smoking and breast cancer risk: original cohort data and meta-analysis. J Natl Cancer Inst 2013;105:515-525.

17 Anderson LM, Chhabra SK, Nerurkar PV, Souliotis VL, Kyrtopoulos SA: Alcohol-related cancer risk: a toxicokinetic hypothesis. Alcohol 1995;12: 97-104.
8 Weber A, Tannapfel A, Wittekind C, Bootz F: Carcinogen-induced site-specific mutagenesis and genetic susceptibility in squamous cell carcinoma of the head and neck. Onkologie 2002;25:8-13.

19 Kohlmeier L: Biomarkers of fatty acid exposure and breast cancer risk. Am J Clin Nutr 1997; 66(suppl 6):S1548-S1556.

20 Smith-Warner SA, Spiegelman D, Yaun SS, van den Brandt PA, Folsom AR, Goldbohm RA, Graham S, Holmberg L, Howe GR, Marshall JR, Miller AB, Potter JD, Speizer FE, Willett WC, Wolk A, Hunter DJ: Alcohol and breast cancer in women: a pooled analysis of cohort studies. JAMA 1998;279:535-540.

21 Zhang SM, Lee IM, Manson JE, Cook NR, Willett WC, Buring JE: Alcohol consumption and breast cancer risk in the Women's Health Study. Am J Epidemiol 2007;165:667-676.

22 Hamajima N, Hirose K, Tajima K, Rohan T, Calle EE, Heath CW Jr, Coates RJ, Liff JM, Talamini R, Chantarakul N, et al.: Alcohol, tobacco and breast cancer - collaborative reanalysis of individual data from 53 epidemiological studies, including 58,515 women with breast cancer and 95,067 women without the disease. Br J Cancer 2002;87:1234-1245.

23 Brennan SF, Cantwell MM, Cardwell CR, Velentzis LS, Woodside JV: Dietary patterns and breast cancer risk: a systematic review and metaanalysis. Am J Clin Nutr 2010;91:1294-1302.

24 Bagnardi V, Rota M, Botteri E, Tramacere I, Islami F, Fedirko V, Scotti L, Jenab M, Turati F, Pasquali E, Pelucchi C, Bellocco R, Negri E, Corrao G, Rehm J, Boffetta P, La Vecchia C: Light alcohol drinking and cancer: a meta-analysis. Ann Oncol 2013;24:301-308.

25 Giacosa A, Adam-Blondon AF, Baer-Sinnott S, Barale R, Bavaresco L, Di Gaspero G, Dugo L, Ellison RC, Gerbi V, Gifford D, Janssens J, La Vecchia C, Negri E, Pezzotti M, Santi L, Rondanelli M: Alcohol and wine in relation to cancer and other diseases. Eur J Cancer Prev 2012;21:103-108. 
26 Gerber B, Muller H, Reimer T, Krause A, Friese $\mathrm{K}$ : Nutrition and lifestyle factors on the risk of developing breast cancer. Breast Cancer Res Treat 2003;79:265-276.

27 Tynes T, Hannevik M, Andersen A, Vistnes AI, Haldorsen T: Incidence of breast cancer in Norwegian female radio and telegraph operators. Cancer Causes Control 1996; 7:197-204.

28 Hansen J: Light at night, shiftwork, and breast cancer risk. J Natl Cancer Inst 2001;93:1513-1515.

29 Lie JA, Roessink J, Kjaerheim K: Breast cancer and night work among Norwegian nurses. Cancer Causes Control 2006;17:39-44.

-30 Fritschi L, Erren TC, Glass DC, Girschik J, Thomson AK, Saunders C, Boyle T, El-Zaemey S, Rogers P, Peters S, Slevin T, D'Orsogna A, de Vocht F, Vermeulen R, Heyworth JS: The association between different night shiftwork factors and breast cancer: a case-control study. Br J Cancer 2013;109: 2472-2480.

\31 Kamdar BB, Tergas AI, Mateen FJ, Bhayani NH, Oh J: Night-shift work and risk of breast cancer: a systematic review and meta-analysis. Breast Cancer Res Treat 2013;138:291-301.

-32 Erren TC, Pape HG, Reiter RJ, Piekarski C: Chronodisruption and cancer. Naturwissenschaften 2008;95:367-382.

33 Fakri S, Al-Azzawi A, Al-Tawil N: Antiperspirant use as a risk factor for breast cancer in Iraq. Eas Mediterr Health J 2006;12:478-482.

34 McGrath KG: An earlier age of breast cancer diagnosis related to more frequent use of antiperspirants/deodorants and underarm shaving. Eur J Cancer Prev 2003;12:479-485.

35 Mirick DK, Davis S, Thomas DB: Antiperspirant use and the risk of breast cancer. J Natl Cancer Inst 2002;94:1578-1580.

36 Darbre PD: Recorded quadrant incidence of female breast cancer in Great Britain suggests a disproportionate increase in the upper outer quadrant of the breast. Anticancer Res 2005;25:2543-2550.

-37 Darbre PD: Underarm antiperspirants/deodorants and breast cancer. Breast Cancer Res 2009;11 (suppl 3):S5.

\38 Hardefeldt PJ, Edirimanne S, Eslick GD: Deodorant use and breast cancer risk. Epidemiology 2013; 24:172.

39 American Society of Plastic Surgery Procedural Statistics: Reconstructive breast surgery, 2013. www.plasticsurgery.org/Documents/news-resources/ statistics/2013-statistics/cosmetic-proceduresnational-trends-2013.pdf (accessed 16 July, 2014).

40 Spear SL, Murphy DK, Slicton A, Walker PS: Inamed silicone breast implant core study results at 6 years. Plast Reconstr Surg 2007;120(7 suppl 1): S8-S16; discussion S17-S18.

41 Bengtson BP, Van Natta BW, Murphy DK, Slicton A, Maxwell GP: Style 410 highly cohesive silicone breast implant core study results at 3 years. Plast Reconstr Surg 2007;120(7 suppl 1):S40-S48.

42 Cunningham B, McCue J: Safety and effectiveness of Mentor's MemoryGel implants at 6 years. Aesthetic Plast Surg 2009;33:440-444.

43 Maxwell GP, Van Natta BW, Murphy DK, Slicton A, Bengtson BP: Natrelle style 410 form-stable silicone breast implants: core study results at 6 years. Aesthet Surg J 2012;32:709-717.

44 Spear SL, Murphy DK: Natrelle round silicone breast implants: core study results at 10 years. Plast Reconstr Surg 2014;133:1354-1361.
45 Stevens WG, Harrington J, Alizadeh K, Berger L, Broadway D, Hester TR, Kress D, d'Incelli R, Kuhne J, Beckstrand M: Five-year follow-up data from the U.S. clinical trial for Sientra's U.S. Food and Drug Administration-approved Silimed(R) brand round and shaped implants with highstrength silicone gel. Plast Reconstr Surg 2012;130: 973-981.

46 US Food and Drug Administration: FDA update on the safety of silicone gel-filled breast implants. www.fda.gov/downloads/MedicalDevices/Productsand MedicalProcedures/ImplantsandProsthetics/Breast Implants/UCM260090.pdf (accessed 2 August, 2008).

47 US Food and Drug Administration: FDA advises women with breast implants. www.fda.gov/forconsumers/consumerupdates/ucm240985.htm (accessed 16 July, 2014).

48 Albuquerque RC, Baltar VT, Marchioni DM: Breast cancer and dietary patterns: a systematic review. Nutr Rev 2014;72:1-17.

49 Aune D, Chan DS, Greenwood DC, Vieira AR, Rosenblatt DA, Vieira R, Norat T: Dietary fiber and breast cancer risk: a systematic review and meta-analysis of prospective studies. Ann Oncol 2012;23:1394-1402.

50 Aune D, Chan DS, Vieira AR, Rosenblatt DA, Vieira R, Greenwood DC, Norat T: Fruits, vegetables and breast cancer risk: a systematic review and meta-analysis of prospective studies. Breast Cancer Res Treat 2012;134:479-493.

51 Boffetta P, Couto E, Wichmann J, Ferrari P, Trichopoulos D, Bueno-de-Mesquita HB, van Duijnhoven FJ, Buchner FL, Key T, Boeing H, et al.: Fruit and vegetable intake and overall cancer risk in the European Prospective Investigation into Cancer and Nutrition (EPIC). J Natl Cancer Inst 2010;102:529-537.

52 World Health Organization (WHO): Factsheet 311: Obesity and overweight. Update August 2014. www.who.int/mediacentre/factsheet/fs311/en/ (accessed on 8 August, 2014).

53 Alexander DD, Morimoto LM, Mink PJ, Cushing CA: A review and meta-analysis of red and processed meat consumption and breast cancer. Nutr Res Rev 2010;23:349-365.

54 Taylor VH, Misra M, Mukherjee SD: Is red meat intake a risk factor for breast cancer among premenopausal women? Breast Cancer Res Treat 2009;117:1-8.

55 Friedenreich CM: The role of physical activity in breast cancer etiology. Semin Oncol 2010;37:297302.

56 McTiernan A, Kooperberg C, White E, Wilcox S, Coates R, Adams-Campbell LL, Woods N, Ockene $\mathrm{J}$ : Recreational physical activity and the risk of breast cancer in postmenopausal women: the Women's Health Initiative Cohort Study. JAMA 2003;290:1331-1336.

57 Wu Y, Zhang D, Kang S: Physical activity and risk of breast cancer: a meta-analysis of prospective studies. Breast Cancer Res Treat 2013;137:869882.

58 Hildebrand JS, Gapstur SM, Campbell PT, Gaudet MM, Patel AV: Recreational physical activity and leisure-time sitting in relation to postmenopausal breast cancer risk. Cancer Epidemiol Biomarkers Prev 2013;22:1906-1912.

59 Kobayashi LC, Janssen I, Richardson H, Lai AS, Spinelli JJ, Aronson KJ: A case-control study of lifetime light intensity physical activity and breast cancer risk. Cancer Causes Control 2014;25:133140.
60 Chlebowski RT: Nutrition and physical activity influence on breast cancer incidence and outcome. Breast 2013;22(suppl 2):S30-S37.

61 Furness S, Roberts H, Marjoribanks J, Lethaby A, Hickey M, Farquhar C: Hormone therapy in postmenopausal women and risk of endometrial hyperplasia. Cochrane Database Syst Rev 2009;(2): CD000402.

62 Marjoribanks J, Farquhar C, Roberts H, Lethaby A: Long term hormone therapy for perimenopausal and postmenopausal women. Cochrane Database Syst Rev 2012;(7):CD004143.

63 Beral V: Breast cancer and hormone-replacement therapy in the Million Women Study. Lancet 2003; 362:419-427.

64 Chlebowski RT, Kuller LH, Prentice RL, Stefanick ML, Manson JE, Gass M, Aragaki AK, Ockene JK, Lane DS, Sarto GE, Rajkovic A, Schenken R, Hendrix SL, Ravdin PM, Rohan TE, Yasmeen S, Anderson G: Breast cancer after use of estrogen plus progestin in postmenopausal women. $\mathrm{N}$ Engl $\mathrm{J}$ Med 2009;360:573-587.

65 Anderson GL, Limacher M, Assaf AR, Bassford T, Beresford SA, Black H, Bonds D, Brunner R, Brzyski R, Caan B, et al.: Effects of conjugated equine estrogen in postmenopausal women with hysterectomy: the Women's Health Initiative randomized controlled trial. JAMA 2004;291:17011712 .

66 Hulley S, Furberg C, Barrett-Connor E, Cauley J, Grady D, Haskell W, Knopp R, Lowery M, Satterfield S, Schrott H, Vittinghoff E, Hunninghake D: Noncardiovascular disease outcomes during 6.8 years of hormone therapy: Heart and Estrogen/ progestin Replacement Study follow-up (HERS II). JAMA 2002;288:58-66.

67 Chlebowski RT, Hendrix SL, Langer RD, Stefanick ML, Gass M, Lane D, Rodabough RJ, Gilligan MA, Cyr MG, Thomson CA, Khandekar J, Petrovitch $\mathrm{H}$, McTiernan A: Influence of estrogen plus progestin on breast cancer and mammography in healthy postmenopausal women: the Women's Health Initiative randomized trial. JAMA 2003; 289:3243-3253.

68 North American Menopause Society: Estrogen and progestogen use in postmenopausal women: 2010 position statement of The North American Menopause Society. Menopause 2010;17:242-255.

69 Gompel A, Rozenberg S, Barlow DH: The EMAS 2008 update on clinical recommendations on postmenopausal hormone replacement therapy. Maturitas 2008;61:227-232.

70 Santen RJ, Allred DC, Ardoin SP, Archer DF, Boyd N, Braunstein GD, Burger HG, Colditz GA, Davis SR, Gambacciani M, et al.: Postmenopausal hormone therapy: an Endocrine Society scientific statement. J Clin Endocrinol Metab 2010;95(7 suppl 1):S1-S66.

71 Sturdee DW, Pines A, Archer DF, Baber RJ, Barlow D, Birkhauser MH, Brincat M, Cardozo L, de Villiers TJ, Gambacciani M, et al.: Updated IMS recommendations on postmenopausal hormone therapy and preventive strategies for midlife health. Climacteric 2011;14:302-320.

72 Giovannucci E, Harlan DM, Archer MC, Bergenstal RM, Gapstur SM, Habel LA, Pollak M, Regensteiner JG, Yee D: Diabetes and cancer: a consensus report. Diabetes Care 2010;33:1674-1685.

73 Alvino CL, Ong SC, McNeil KA, Delaine C, Booker GW, Wallace JC, Forbes BE: Understanding the mechanism of insulin and insulin-like growth factor (IGF) receptor activation by IGF-II PLoS One 2011;6:e27488. 
74 Tzivion G, Dobson M, Ramakrishnan G: FoxO transcription factors; regulation by AKT and 143-3 proteins. Biochim Biophys Acta 2011;1813: 1938-1945.

75 Fleming HE, Janzen V, Lo Celso C, Guo J, Leahy KM, Kronenberg HM, Scadden DT: Wnt signaling in the niche enforces hematopoietic stem cell quiescence and is necessary to preserve self-renewal in vivo. Cell Stem Cell 2008;2:274-283.

76 Xu CX, Zhu HH, Zhu YM: Diabetes and cancer: associations, mechanisms, and implications for medical practice. World J Diabetes 2014;5:372-380.

77 World Health Organization, Diabetes Programme: Country and regional data on diabetes. http://www. who.int/diabetes/facts/world_figures/en/ (accessed on 19 June, 2014)

78 Verlato G, Zoppini G, Bonora E, Muggeo M: Mortality from site-specific malignancies in type 2 diabetic patients from Verona. Diabetes Care 2003;26: 1047-1051.
79 Stattin P, Bjor O, Ferrari P, Lukanova A, Lenner P, Lindahl B, Hallmans G, Kaaks R: Prospective study of hyperglycemia and cancer risk. Diabetes Care 2007;30:561-567.

80 Zhou XH, Qiao Q, Zethelius B, Pyorala K, Soderberg S, Pajak A, Stehouwer CD, Heine RJ, Jousilahti P, Ruotolo G, Nilsson PM, Calori G, Tuomilehto J: Diabetes, prediabetes and cancer mortality. Diabetologia 2010;53:1867-1876.

81 Jee SH, Ohrr H, Sull JW, Yun JE, Ji M, Samet JM: Fasting serum glucose level and cancer risk in Korean men and women. JAMA 2005;293:194-202.

82 Seshasai SR, Kaptoge S, Thompson A, Di Angelantonio E, Gao P, Sarwar N, Whincup PH, Mukamal KJ, Gillum RF, Holme I, et al.: Diabetes mellitus, fasting glucose, and risk of cause-specific death. N Engl J Med 2011;364:829-841.

83 Larsson SC, Mantzoros CS, Wolk A: Diabetes mellitus and risk of breast cancer: a meta-analysis. Int J Cancer 2007;121:856-862.
84 Schernhammer ES, Hankinson SE, Rosner B, Kroenke CH, Willett WC, Colditz GA, Kawachi I: Job stress and breast cancer risk: the Nurses' Health Study. Am J Epidemiol 2004;160:10791086.

85 Price MA, Tennant CC, Butow PN, Smith RC, Kennedy SJ, Kossoff MB, Dunn SM: The role of psychosocial factors in the development of breast carcinoma: Part II. Life event stressors, social support, defense style, and emotional control and their interactions. Cancer 2001;91:686-697.

86 Protheroe D, Turvey K, Horgan K, Benson E, Bowers D, House A: Stressful life events and difficulties and onset of breast cancer: case-control study. BMJ 1999;319:1027-1030.

87 Sprague BL, Trentham-Dietz A, Egan KM, TitusErnstoff L, Hampton JM, Newcomb PA: Proportion of invasive breast cancer attributable to risk factors modifiable after menopause. Am J Epidemiol 2008;168:404-411. 